\title{
c.
}

Кравченко О.А.

\section{УСЛОВИЯ ОБЕСПЕЧЕНИЯ КОНСТИТУЦИОННОГО ПРИНЦИПА ДОСТОВЕРНОСТИ ОПРЕДЕЛЕНИЯ ВОЛЕИЗЪЯВЛЕНИЯ НАРОДА}

\begin{abstract}
Аннотация: статья посвящена выявлению условий обеспечения конституционного принципа достоверности волеизъявления народа. Из проведенного в статье конституционного анализа, сделан следуюший вывод: правовые нормы Конституции Российской Федерачии содержат необходимый фундамент и тот необходимый перечень правовых средств при помощи которых можно установить условия обеспечивающие конституционный принцип достоверности определения волеизъявления народа, не имеющий каких-либо серьёзных недостатков и не вызываюший сомненийу общества. Иными словами, из Конституиии РФ не прямо, а косвенно выводится следующее: результаты волеизъявления народа, установленные органами власти организующими выборы, должны (могут) подвергаться ревизии любым избирателем, чтобы можно было исправить допущенные ошибки. Установлены необходимые условия для организаиии такой системы голосования, которая отвечала бы конституичинному приниипу достоверности определения результатов волеизъявления народа с сохранением тайны голосования, к которым относятся следуюшие: 1) наличие механизма проверки избирателем учета своего волеизъявления (голоса); 2) наличие механизма защиты избирателем своего голоса в случае выявления несоответствий; 3) наличие механизма проверки избирателем достоверности определения результатов голосования; 4) наличие механизма защиты избирателем волеизъявления народа в случае выявления несоответствий; 5) наличие механизма проверки политической партией достоверности определения результатов голосования; 6) наличие механизма защиты политической партией волеизъявления народа в случае выявления несоответствий; 7) наличие механизма наказания ответственных лии за выявленные и подтвержденные в судебном порядке факты искажения волеизъявления народа; 8) наличие механизма поошрения ответственных и заинтересованных лии за выявленные и подтвержденные в судебном порядке факты искажения волеизъявления народа.

Abstract: This article identifies the conditions necessary to ensure the constitutional principle of free and fair elections/ referenda. Analysis of the Constitution of the Russian Federation reveals that its articles provide the required basis and the necessary list of legal means by which to establish the conditions to ensure the constitutional principle of free and fair elections/referenda; that is, that the outcome of an election/referendum is free from any major flaws and is not doubted by the populace. The Constitution of the Russian Federation indirectly leads to the deduction that the results of elections/ referenda, as determined by the authorities organizing such, have to be (and are able to be) audited by any voter so that the errors may be corrected. It is possible to establish the conditions necessary for the organization of a voting system that would embody the constitutional principle of free and fair elections while preserving the secrecy of the ballot. Such conditions are: 1 ) the existence of a mechanism by which voters can verify a record of their vote; 2 ) the existence of a mechanism by which voters can safeguard their vote in case of discrepancies; 3 ) the existence of a mechanism by which voters can verify the authenticity of the voting results; 4) the existence of a mechanism for the protection of voters of an election/referendum in case of discrepancies; and 5 ) the existence of mechanism by which a political party can verify the reliability of the voting results; 6) the existence of a mechanism for the protection of a political party involved in an election/referendum in case of discrepancies; 7) the existence of a mechanism to punish individuals who are identified and confirmed in court as being responsible for interfering with an election/referendum; and 8 ) the existence of a mechanism to encourage responsible and concerned individuals to detect and prove in court evidence of electoral interference.
\end{abstract}

Ключевые слова: конституция, конституционный принцип, условия конституционного принципа, народ, волеизъявление, достоверность, избирательные комиссии, итоги голосования, результаты выборов, источник власти Keywords: constitution, constitutional principles, conditions of a constitutional principle, populace, elections, verification, election commissions, voting results, election results, source of power 
$\Pi$ од конституционным принципом достоверности определения волеизъявления народа, автором понимается, вытекающий из положений ст. 3 Конституции Российской Федерации о суверенитете народа, принцип, общее начало, определяющее организацию голосования, подведение его итогов и определение результатов голосования, при которых результат волеизъявления народа отражается в официальных документах об итогах голосования и определении результатов выборов без какого-либо искажения, то есть официальные результаты голосования соответствуют или адекватно отражают волеизъявление народа.

В существующей в нашей стране системе организации голосования, имеются возможности по искажению волеизъявления народа (раскрытие таковых не является целью настоящей статьи, речь о них идет в других статьях $\left.{ }^{1}\right)$ и есть опасность того, что такие возможности могут быть реализованы, а потому необходимы механизмы способные защитить волеизъявления народа от искажения.

Для того, чтобы органы представительной демократии были сформированы на основе действительного, не искаженного волеизъявления народа, это волеизъявление должно быть достоверно определено, а потому надо установить необходимые условия, обеспечивающие конституционный принцип достоверности определения волеизъявления народа.

Говоря о достоверности определения волеизъявления избирателей, автор понимает под данной правовой конструкцией не только определение или проверку результатов уже состоявшегося голосования или состоявшегося волеизъявления избирателей на предмет их прямого или ошибочного искажения членами избирательных комиссий, при котором волеизъявление избирателей неправильно учтено или учтено неверно (например, внесением недостоверных данных в избирательные документы), но и определение того, могло ли иметь место нивелирование волеизъявления избирателей, а именно тех избирателей, которые выразили или изъявили свою волю и проголосовали, но волеизъявление, которых при этом нивелировано (например, путем незаконного вброса бюллетеней, многократным голосованием одним лицом, в том числе и за других лиц, а также тому подобное).

\footnotetext{
${ }^{1}$ Кравченко O.A. Понятие и классификация искажений волеизъявления народа // Академический юридический журнал. 2013. № 3 (53). С. 19-23; Кравченко О.А Вопросы искажения волеизъявления народа при подведении итогов голосования // Актуальные проблемы российского права. 2013. № 9 (34). С. 1089-1093.
}

В нашей стране определением волеизъявления народа занимаются избирательные комиссии, в большей части, участковые избирательные комиссии и вышестоящие по отношению к ним.

Так, из п. 7 ст. 3 Федерального закона от 12 июня 2002 года № 67-Ф3 «Об основных гарантиях избирательных прав и права на участие в референдуме граждан Российской Федерации» следует, что выборы организуют и проводят комиссии, вмешательство в деятельность комиссий со стороны законодательных (представительных) и исполнительных органов государственной власти, органов местного самоуправления, организаций, должностных лиц, иных граждан не допускается.

Кроме того, в соответствии с федеральным законодательством установление итогов голосования, определение результатов выборов является исключительным правом соответствующих избирательных комиссий, поскольку согласно п. 6 ст. 27 Федерального закона от 12 июня 2002 года № 67-Ф3 «Об основных гарантиях избирательных прав и права на участие в референдуме граждан Российской Федерации» участковая избирательная комиссия проводит подсчет голосов, устанавливает итоги голосования на избирательном участке, участке референдума, составляет протокол об итогах голосования и передает его в территориальную комиссию.

В связи с чем, деятельность участковых избирательных комиссий очень важна, поскольку именно они не только выявляют волеизъявление народа, но и отражают его в своих официальных документах.

Могут ли участковые избирательные комиссии достоверно определять волеизъявление народа?

Избирательные комиссии состоят из людей, граждан Российской Федерации, действия которых не застрахованы от совершения правонарушений и допущения как умышленных, так и технических ошибок при организации голосования и подведении его итогов. В том случае, когда такие правонарушения и ошибки осуществляются применительно к высшему непосредственному выражению власти всего нашего народа, они ставят под сомнение суверенитет народа и создают предпосылки для захвата власти народа, теми кандидатами и политическими партиями, в пользу которых совершены правонарушения и допущены ошибки.

Существует мнение, авторов А.С. Автономова, А.Ю. Бузина, А.В. Иванченко, В.И. Кривцова, А.В. Кынева, А.Е. Любарева, которые указывают, что система избирательных комиссий находится в сильной зависимости от исполнительных органов власти, при этом исполнительная власть не является беспристрастной. Эти же авторы указывают, 


\section{Право и политика 11 (166) • 2013}

что такая зависимость обусловлена, в том числе персональным составом избирательных комиссий, формирование которых в значительной степени осуществляется исполнительной властью. ${ }^{2}$

В связи с чем, достоверность волеизъявления народа не может презюмироваться только лишь указанием на то обстоятельство, что такое волеизъявление установили избирательные комиссии, а потому оно достоверно. Этого явно недостаточно.

Как отмечал, известный теоретик демократии Р. Даль: «Чтобы удовлетворять требованиям демократии, присущие ей права должны быть реально доступны гражданам. Зафиксировать права на бумаге, возвести их в закон или даже записать в конституцию еще недостаточно - они должны быть практически внедрены в повседневную жизнь общества и доступны для граждан». ${ }^{3}$

Кроме того, как быть в том случае, когда выявилось недостоверное определение волеизъявления народа избирательными комиссиями? В таком случае, нужны эффективные средства как защиты от искажения волеизъявления народа, так и восстановления нарушенных прав конкретного избирателя.

Правильно, отмечал С.С. Алексеев: «Права и свободы человека нуждаются не просто в защите, а в обеспечении... в виде широкой системы государственноправовых мер, призванных не только гарантировать действенную реакцию на каждый случай нарушения прав, но и на то, чтобы предупредить, по возможности, исключить сами нарушения». ${ }^{4}$ В том же случае, когда речь идет о нарушении избирательных прав граждан, то значение обеспечения такого права возрастает многократно, поскольку, во-многом, реализация иных прав человека и гражданина будет зависеть от того, насколько правильно были реализованы избирательные права граждан.

Таким образом, требует решения, задача наполнения конституционного принципа достоверности определения волеизъявления народа реальным содержанием, путем выявления необходимых и достаточных условий при котором такой принцип был бы обеспечен. Сущность указанных условий проявляется в правовом гарантировании достоверного определения

\footnotetext{
${ }^{2}$ Российские выборы в контексте международных избирательных стандартов: Материалы международной конференции / Под ред. А.В. Иванченко и А.Е. Любарева. М.: Аспект Пресс, 2006. С. 58.

${ }^{3}$ Даль Р. О демократии / Пер. с англ. А.С. Богдановского; Под ред. О.А. Алякринского. М.: Аспект Пресс, 2000. С. 52.

${ }^{4}$ Алексеев С.С. Демократические реформы и конституция. М.: Издательский центр газеты «Позиция», 1992. С. 35-36.
}

волеизъявления народа, то есть нормальной реализации избирательных прав граждан на таких стадиях избирательного процесса как организация голосования и подведение его итогов.

Правовые основы обеспечения конституционного принципа достоверности определения волеизъявления народа могут вытекать из норм права закрепленных в Конституции Российской Федерации (далее Конституция РФ).

Так, Конституция РФ в ст. 2 декларирует, что человек, его права и свободы являются высшей ценностью и признание, соблюдение и защита прав и свобод человека и гражданина - обязанность государства. В связи с чем, через конституцию обеспечивается высокий юридический статус личности, первичного субъекта демократии как народовластия, ${ }^{5}$ а значит государство берет на себя обязанность по реализации избирательных прав гражданина таким образом, чтобы его волеизъявление было достоверно отражено в официальных избирательных документах. Как верно отмечено в науке конституционного права: «Не человек создан для государства, а государство для человека - таков теперь главный принцип их отношений». ${ }^{6}$

В ст. 3 Конституции РФ, где народ провозглашен единственным источником власти, также указывается, что народ осуществляет свою власть как непосредственно, так и через органы государственной власти и местного самоуправления. Из ч. 3 ст. 3 Конституции РФ следует, что высшим непосредственным выражением власти народа являются референдум и свободные выборы. Хотя в Конституции РФ прямо не закреплено, но из её положений косвенно выводится, что власть народа осуществляется выражением волеизъявления на выборах путем голосования, результаты которого должны быть достоверно определены, поскольку иное положение, не означало бы выражения власти народа.

В ч. 1 ст. 7 Конституции РФ закреплено положение о том, что политика Российской Федерации направлена на создание условий, обеспечивающих достойную жизнь и свободное развитие человека, что означает, том числе создание государством таких условий при проведении голосования и подведении его итогов, при которых волеизъявления народа определено достоверно.

Норма права, закрепленная в ст. 15 Конституции РФ устанавливает, что Конституция РФ имеет высшую юридическою силу, прямое действие и применяется на

\footnotetext{
${ }^{5}$ Нудненко Л.А. Теория демократии. М.: Юристъ, 2001. С. 69.

${ }^{6}$ Баглай М.В., Габричидзе Б.Н. Конституционное право Российской Федерации. М.: 1996. С. 98-99.
} 
всей территории Российской Федерации. Указанная норма права является основой, во-первых, для организации такого голосования граждан Российской Федерации, при которых официальные его результаты адекватно отражают волеизъявление избирателей, во-вторых, для совершенствования избирательного законодательства, в таком направлении, при котором: 1) у граждан Российской Федерации не должно возникать сомнений в том, что их волеизъявление официальными властями определено недостоверно; 2) избиратели, при соблюдении тайны голосования, могли бы проверить правильность и достоверность отражения их волеизъявления в официальных избирательных документах; 3) избиратели в случае выявления неадекватного отражения их волеизъявления в официальных избирательных документах, могли бы, эффективно защитить право на достоверное определение результатов волеизъявления, а также восстановить нарушенные избирательные права.

Конституция РФ в ст. 17 закрепляет, что основные права и свободы человека неотчуждаемы и принадлежат каждому от рождения. Указанное конституционное положение позволяет каждому избирателю требовать от всех государственных органов и их должностных, в том числе и органов осуществляющих организацию выборов, полной и правильной реализации его избирательных прав, а также осуществлять контроль за их соблюдением.

Согласно ст. 18 Конституции РФ права и свободы человека являются непосредственно действующими и они определяют смысл, содержание и применение законов, деятельность законодательной и исполнительной власти, местного самоуправления и обеспечиваются правосудием. Поскольку реализация прав гражданина, в том числе, право избирать и быть избранным невозможно без участия государства, то органы последнего должны обеспечивать создание таких механизмов, которые исключают недостоверное определение волеизъявления народа при осуществлении голосования и подведении его итогов.

То обстоятельство, что именно на органы государственной власти возложено обеспечение избирательных прав граждан, подтверждается правовыми позициями Конституционного суда Российской Федерации. Так, из п. 2.1 Постановления Конституционного Суда Российской Федерации от 7 июля 2011 года № 15-П «По делу о проверке конституционности положений части 3 статьи 23 Федерального закона «Об общих принципах организации местного самоуправления в Российской Федерации» и частей 2 и 3 статьи 9 Закона Челябинской области «О муниципальных выборах в Челябинской области» в связи с жалобами Уполномоченного по правам человека в Российской Федерации и граждан И.И. Болтушенко и Ю.А. Гурмана» следует, что законодатель - исходя из того, что свободные и справедливые выборы, в том числе в органы местного самоуправления, как одна из основ конституционного строя Российской Федерации, предполагают необходимость их проведения с разумной периодичностью в условиях состязательности и открытости, - обязан устанавливать такое правовое регулирование в этой области, которое надлежащим образом гарантировало бы избирательные права граждан и легитимацию органов публичной власти, формируемых по итогам демократических выборов, не допуская искажения результатов волеизъявления избирателей.

В соответствии с ч. 2 ст. 24 Конституции РФ органы государственной власти и органы местного самоуправления, их должностные лица, обязаны обеспечить каждому возможность ознакомления с документами и материалами, непосредственно затрагивающими его права и свободы, если иное не предусмотрено законом. Указанное право позволяет избирателю знакомиться с теми избирательными документами, которые содержат сведения о результатах его волеизъявления при голосовании, выявлять недостоверный учет такого волеизъявления.

Конституция РФ в ч. 4 ст. 29 гарантирует каждому право искать, получать, передавать, производить, и распространять информацию любым законным способом. Конституционная гарантия отраженная в этой норме обеспечивает права как отдельного гражданина, так и всего народа на достоверную и необходимую информацию. Данная гарантия создаёт необходимые условия для получения избирателем информации об официально учтенном его голосе.

Обеспечение достоверного волеизъявления избирателей невозможно без широкого участия общественных объединений на таких стадиях избирательного процесса, как организация голосования и подведение его итогов, в связи с чем, важное значение приобретает ст. 30 Конституции РФ которая закрепляет право на объединение и свободу деятельности общественных объединений. При этом, особую роль в избирательном процессе обретают такие общественные объединения, которые непосредственно участвуют в проведении выборов - политические партии. То обстоятельство, что политические партии содействуют процессу волеобразования народа, указано в п. 2.2 Постановления Конституционного Суда Российской Федерации от 7 
DOI: $10.7256 / 1811-9018.2013 .11 .10047$

При цитировании этой статьи сноска на dоі обязательна

\section{Право и политика 11 (166) • 2013}

июля 2011 года № 15-П «По делу о проверке конституционности положений части 3 статьи 23 Федерального закона «Об общих принципах организации местного самоуправления в Российской Федерации» и частей 2 и 3 статьи 9 Закона Челябинской области «О муниципальных выборах в Челябинской области» в связи с жалобами Уполномоченного по правам человека в Российской Федерации и граждан И.И. Болтушенко и Ю.А. Гурмана» из которого следует, что поскольку провозглашенное в преамбуле Конституции Российской Федерации и структурированное в ряде ее статей, прежде всего в статье 3, осуществление власти в Российской Федерации ее гражданами, составляющими в своей совокупности многонациональный народ Российской Федерации, предполагает формирование политической воли народа, определяющей деятельность публичной власти, именно политические партии, на которые возложена соответствующая публичная функция, содействуют, по смыслу статьи 13 Конституции РФ, процессу волеобразования народа в условиях открытости и свободы создания и деятельности самих политических партий, отвечающих конституционным критериям демократии, что, в свою очередь, требует согласованного функционирования избирательной системы и многопартийной политической системы, способной адекватно выражать интересы и потребности общества как в Государственной Думе, являющейся, по смыслу Конституции Российской Федерации, организационной формой представительства воли и интересов многонационального народа Российской Федерации, так и в представительных органах государственной власти субъектов Российской Федерации и представительных органах муниципальных образований.

В силу ч. 1 ст. 32 Конституции РФ граждане Российской Федерации имеют право участвовать в управлении делами государства как непосредственно, так и через своих представителей. Данное конституционное положение означает, что граждане вправе выбирать любые правовые средства для участия в управлении делами государства, в том числе и такие, которые позволяют им проверять деятельность органов государства организующих выборы в части правильности учета голосов избирателей, достоверности определения волеизъявления народа.

В соответствии с ч. 2 ст. 32 Конституции РФ граждане Российской Федерации имеют право избирать и быть избранными в органы государственной власти и органы местного самоуправления, а также участвовать в референдуме. Указанное право не ограничивается только лишь опусканием избирателем бюллетеня в урну для голосования. Право избирать и быть избранным означает недопустимость искажения кем бы то ни было, в какой бы то ни было форме, волеизъявления не только конкретного избирателя, но и других избирателей, поскольку в таком случае голоса избирателей имеют неравный вес.

Норма права закрепленная в ст. 45 Конституции РФ гарантирует государственную защиту прав и свобод человека и гражданина и предоставляет каждому право защищать свои права и свободы всеми способами незапрещенными законом. Из названной нормы права следует, что способы защиты прав не ограничены и их перечень неисчерпывающий, а потому создание механизма обеспечивающего достоверное волеизъявление народа будет одним из правовых способов такой защиты.

Согласно ст. 46 Конституции РФ каждому гарантируется судебная защита его прав и свобод, то есть решения и действия (или бездействие) органов государственной власти, органов местного самоуправления, общественных объединений и должностных лиц могут быть обжалованы в суд. Из данного положения следует - чем больше у избирателей будет возможностей в проверке достоверности учета их волеизъявлений организаторами голосования, с возможностью отражения такого волеизъявления не только в официальных документах избирательных комиссий, но и в документах предоставляемым проголосовавшим избирателям, тем эффективнее будет механизм судебного рассмотрения жалоб на недостоверное волеизъявление народа, поскольку избиратели будут обладать доказательствами нарушения своих прав и возможностями их использования в суде.

Проведенный конституционный анализ, позволяет сделать следующий вывод.

Из норм Конституции РФ выводится следующее - эти нормы содержат фундамент, допускающий выработку правовых средств, с помощью которых возможно установить механизм, обеспечивающий конституционный принцип достоверности определения волеизъявления народа, не имеющий каких-либо серьёзных недостатков и не вызывающий сомнений у общества. Иными словами, из Конституции РФ не прямо, а косвенно выводится следующее: результаты волеизъявления народа, установленные органами власти, организующими выборы, должны (могут) подвергаться ревизии любым избирателем для того, чтобы можно было исправить ошибки, в тех случаях, когда они были допущены.

Здесь может возникнуть вопрос о соблюдении тайны голосования при ревизии избирателем своего официально учтенного голоса. 
В нашей стране институт тайны голосования установлен так, что информация о том, как проголосовал конкретный гражданин, скрыта, в том числе и от него самого. Поэтому даже в том, случае, если гражданин пожелает, пусть даже в тайне от всех, с сохранением тайны своего голосования от других, проверить, учтен ли его голос и если учтен, то правильно ли учтен, он не сможет этого сделать, поскольку отсутствует механизм такой проверки.

Система определения волеизъявления нашего народа основана на презумпции доверия к избирательным комиссиям всех уровней. То как определили итоги голосования и результаты выборов избирательные комиссии и зафиксировали их в избирательных документах, и является определением волеизъявления народа.

По справедливому замечанию А.В. Иванченко, деятельность избирательных комиссий направлена на то, чтобы оформить волю народа, придать ей нормативный (обязательный) характер для всех государственных органов, должностных лиц, общественных объединений, граждан.?

Но правильно ли определяют итоги голосования и результаты выборов избирательные комиссии, правильно ли они фиксируют волеизъявление народа в своих избирательных документах, правильно (адекватно) ли учитывают голоса избирателей?

Как известно, волеизъявление народа осуществляется путем голосования, а результаты непосредственного выражения власти народа, то есть результаты волеизъявления народа фиксируются в избирательных документах составленных избирательными комиссиями.

Таким образом, между волеизьявлением народа и результатами непосредственного выражения власти народа оказываются посредники - избирательные комиссии, или как отмечает А.В. Иванченко избирательные комиссии являются основным звеном в технологической цепочке реализации конституционного права граждан избирать и быть избранным. ${ }^{8}$

Роль избирательных комиссий в механизме определения волеизъявления народа, столь значительна, что они выступают единственными органами, которые не только официально извещают общество о результатах голосования и итогах выборов, но и обеспечивают легальный конституционный характер передачи

\footnotetext{
${ }^{7}$ Иванченко А.В. Избирательные комиссии в Российской Федерации: история, теория, практика. (Монографическое исследование). М.: Издательство «Весь Мир», 1996. С. 52.

${ }^{8}$ Иванченко А.В. Избирательные комиссии в Российской Федерации: история, теория, практика. (Монографическое исследование). М.: Издательство «Весь Мир», 1996. С. 75.
}

государственной власти победившей на выборах политической силе. ${ }^{9}$

В связи со своим высоким статусом, важным и существенным значением, избирательные комиссии не могут оставаться как без народного контроля, так и без соответствующего механизма проверки результатов их деятельности.

Не всегда справляется с поставленными перед ней задачами, существующая система гарантий по обеспечению беспристрастности, независимости, гласности и законности деятельности избирательных комиссий, предусмотренная, в частности ст. 30 Федерального закона от 12 июня 2002 года № 67-Ф3 «Об основных гарантиях избирательных прав и права на участие в референдуме граждан Российской Федерации», в которой речь идет о том, что на всех заседаниях избирательных комиссий вправе присутствовать члены вышестоящих комиссий, кандидаты доверенные лица, уполномоченные представители, а во время голосования и подсчета голосов - также наблюдатели, иностранные (международные) наблюдатели. Даже в том случае, если указанные лица зафиксировали нарушения в деятельности избирательных комиссий при подведении итогов голосования и обратились в суд за восстановлением своих прав, то доказать нарушение в суде и отменить итоги голосования бывает практически невозможно. Освещение судебной практики по делам об оспаривании итогов голосования не входит в задачи настоящей статьи и в ней не рассматривается, в виду того, что этот вопрос был рассмотрен в других статьях..$^{10}$

Могут ли избирательные комиссии исказить волеизъявление народа? Могут, если пожелают совершить умышленное правонарушение или если допустят ошибку, в том числе техническую. Кроме того, познать истину после установления итогов голосования и определения результатов выборов бывает уже невозможно. Так, по итогам выборов Президента РФ в Омской области было возбуждено уголовное дело по фактам завышения явки избирателей и числа голосов, поданных за одного из кандидатов, на 8844. ${ }^{11}$ Дело прекращено из-за отсутствия первичной избирательной документации, то есть первых экземпляров протоко-

\footnotetext{
9 Там же.

${ }^{10}$ Кравченко O.A. Вопросы процессуальных гарантий волеизъявления народа при формировании институтов народного представительства // Адвокатская практика. 2013. № 1. С. 39-41; Кравченко О.А. Процессуальные гарантии обеспечения достоверности волеизъявления народа: вопросы практики // Советник юриста. 2013. № 5. С. 69-79.

${ }^{11}$ Бюллетени изрезали в лапшу // Новая газета. 2008. 22 мая.
} 


\section{Право и политика 11 (166) • 2013}

лов участковых и территориальных избирательных комиссий, которые 20 марта 2008 года были ошибочно уничтожены в ОАО «Омсккровля». ${ }^{12}$

Представляется, что результат выражения высшей непосредственной власти народа должен быть защищен с использованием специального механизма проверки народом результатов своего волеизъявления оформленных избирательными комиссиями.

При отсутствии механизма проверки народом фиксации своего волеизъявления в избирательных документах избирательных комиссий, невозможно с достоверностью установить, правильно ли учтено волеизъявление народа и правильно ли определены результаты выражения высшей непосредственной власти народа.

В связи с чем, необходимым условием обеспечения принципа достоверности определения волеизъявления народа является наличие механизма проверки народом (избирателями) фиксации своего волеизъявления в избирательных документах избирательных комиссий, поскольку именно эти документы являются правовым основанием установления результатов выражения непосредственной власти народа в нашей стране.

Такой механизм при сохранении тайны голосования можно обеспечить предоставлением гражданину письменного документа, о содержании которого было бы известно только ему, в котором было бы зафиксировано его волеизъявление с указанием на номер бюллетеня использованного им при голосовании, причем при распределении бюллетеней в случайном порядке, а также указанием в протоколе об итогах голосования участковой избирательной комиссии на номер бюллетеня и соответствующее ему волеизъявление избирателя, с обязательным размещением такого протокола в сети Интернет.

При этом, не может быть речи о том, что от названного механизма пострадает тайна голосования, или иным образом будет нарушен принцип свободных выборов, поскольку содержание письменного документа оставляемого у гражданина он вправе не раскрывать. Только сам избиратель может проверить правильность учета своего голоса, необходимость и целесообразность такой проверки полностью зависят от его решения. Сторонние лица не вправе проверять достоверность учета голоса избирателя, без соответствующего решения избирателя. В целях недопустимости контроля за волеизъявлением избирателя следует установить ответ-

\footnotetext{
${ }^{12}$ Колюшин Е.И. Выборы и избирательное право в зеркале судебных решений: монография. 2-е издание переработанное и дополненное. М.: Норма: ИНФРА-М, 2012. С. 75-77.
}

ственность тех лиц, которые потребуют у избирателя раскрыть тайну его голосования.

Кроме того, избиратель должен иметь возможность, проверять (без нарушения тайны голосования) и защищать не только свое волеизъявление, но и волеизъявление других избирателей, то есть волеизъявление всего народа, что в полной мере соответствует ценностям гражданского общества и демократии. Иными словами, в том, случае, когда гражданин считает, что им выявлено искажение волеизъявление народа, он должен иметь возможность судебном порядке доказать это, чем устранить такое искажение. Ведь, не может существовать демократии тогда, когда органы власти сформированы на основе недостоверного волеизъявления народа. В рамках данной статьи нет цели обосновывать приведенный довод, подробнее его раскрывает другая статья. ${ }^{13}$

Таким образом, необходимым условием обеспечения конституционного принципа достоверности волеизъявления народа является наличие механизма проверки избирателем и народом в целом, достоверности определения результатов голосования.

В связи с тем, что основными игроками на политическом поле, в том числе на выборах, являются политические партии, то и они должны иметь соответствующие механизмы, обеспечивающие конституционный принцип достоверности волеизъявления народа.

Так, политические партии участвующие в выбоpax, должны иметь право на проверку адекватности отражения в официальных документах результатов волеизъявления избирателей, а в случае выявления несоответствий, иметь возможность защитить волеизъявление народа, в том числе и в своих интересах.

Условиями обеспечения конституционного принципа достоверности определения волеизъявления народа будут являться: механизм проверки политической партией достоверности определения результатов голосования; механизм защиты политической партией волеизъявления народа в случае выявления ею несоответствий волеизъявления народа с официальными избирательными документами.

Таким образом, конституционное право на участие в управлении делами государства, в том числе право избирать (активное избирательное право) обеспеченное конституционным принципом достоверности определения волеизъявления народа, включает в себя не только право на голосование, но и право на самостоятельную проверку: 1) избирателем достоверности учета его во-

\footnotetext{
${ }^{13}$ Кравченко О.А. Демократия как достоверное волеизъявление народа // Вестник Пермского университета. Юридические науки. 2013. Выпуск 1(19). С. 54-58.
} 
леизъявления в официальных протоколах об итогах голосования, которые должны находиться в открытом доступе; 2) избирателем достоверности определения результатов голосования путем обеспечения доступности для каждого избирателя всех первичных протоколов об итогах голосования; 3) политической партией достоверности определения результатов голосования на всех избирательных участках; 4) наблюдателем достоверности определения результатов голосования на соответствующем избирательном участке.

Под самостоятельной проверкой избирателем достоверности учета его волеизъявления понимается сверка своего волеизъявления с зафиксированным волеизъявлением в официальном протоколе об итогах голосования при помощи использования идентификационного номера бюллетеня, причем, с одной стороны, данный номер должен быть указан в предоставляемом избирателю подтверждающем документе, а с другой стороны, официальный протокол об итогах голосования должен быть составлен таким образом, чтобы в нем учитывались голоса всех принявших участие в голосовании избирателей и их волеизъявление, при этом, чтобы сохранить тайну голосования вместо персональных данных избирателя в названном протоколе указываются идентификационные номера бюллетеней.

Под самостоятельной проверкой избирателем достоверности определения результатов голосования понимается самостоятельный подсчет избирателем голосов отраженных во всех протоколах об итогах голосования по конкретному политическому решению (выборы депутатов, списков депутатов, должностного лица, проведения референдума).

Под самостоятельной проверкой политической партией достоверности определения результатов голосования на всех избирательных участках понимается самостоятельный подсчет политической партией голосов отраженных во всех протоколах об итогах голосования по конкретному политическому решению, причем политической партии, участвовавшей в выборах, должны быть предоставлены все оригиналы протоколов об итогах голосования на каждом избирательном участке с отражением в них номера бюллетеня и соответствующего волеизъявления избирателя. В случае реализации электронного голосования под самостоятельной проверкой политической партией достоверности определения результатов голосования на всех избирательных участках понимается не только выдача всех оригиналов протоколов об итогах голосования по конкретному политическому решению и подсчет данных содержащихся в них, но и выдача подтвержда- ющих документов о волеизъявлении всех избирателей принявших участие в голосовании с сохранением тайны голосования и самостоятельный подсчет и обработка названных документов.

Под самостоятельной проверкой наблюдателем достоверности определения результатов голосования на соответствующем избирательном участке понимается выдача оригинала (оригиналов) протокола (протоколов) об итогах голосования на соответствующем избирательном участке с отражением в них номера бюллетеня и соответствующего волеизъявления избирателя и сверка с официально опубликованным постановлением о результатах голосования, в котором указываются сведения из выданного ему протокола об итогах голосования.

Кроме того, простого механизма проверки народом или избирателем фиксации волеизъявления в избирательных документах недостаточно для обеспечения конституционного принципа достоверности определения волеизъявления народа.

Как быть в том случае, если при наличии названного механизма проверки своего волеизъявления, народ установит неправильность отражения своего волеизъявления в избирательных документах? В этом случае, необходимо пользоваться конституционным правом на судебную защиту.

Таким образом, условием обеспечения конституционного принципа достоверности определения волеизъявления народа является наличие механизмов защиты избирателем волеизъявления народа в случае выявления несоответствий с официальными избирательными документами.

Для реализации права на судебную защиту, при отстаивании достоверности определения волеизъявления народа, необходимо обладание документами, которые, безусловно бы принимались судом в качестве доказательств, то есть обладающими определенной юридической силой.

Человек, гражданин, избиратель - частица народа, а значит и частица суверенной власти народа, могущий осуществлять свою власть непосредственно. Подробнее о суверенной власти народа выражающейся через его волю говориться в другой статье. ${ }^{14}$ Пользуясь предоставленной гражданину властью, он реализует конституционное право избирать и быть избранным, путем голосования. Причем голоса по-

${ }^{14}$ Кравченко О.А. Суверенитет и воля народа (избирателей) // Вестник Тверского государственного университета. 2013. № 13. Серия «Право». Выпуск 34. С. 58-73. 
DOI: $10.7256 / 1811-9018.2013 .11 .10047$

При цитировании этой статьи сноска на доі обязательна

\section{Право и политика 11 (166) • 2013}

данные избирателями должны иметь равный вес, что вытекает из равенства прав всех избирателей на управление делами государства посредством голосования. Как отмечает Л.А. Нудненко: «Принципов выборов является критерий «один человек - один голос». Демократия не допускает, чтобы при голосовании индивид имел более одного голоса». ${ }^{15}$ По словам Р. Даля: «Если мы уверены, что все члены ассоциации одинаково и достаточно хорошо разбираются в существе вопроса, для того чтобы принимать участие в решениях ассоциации, то почему должен нарушаться принцип «один человек - один голос». ${ }^{16}$ Он же указывал: «Если вы лишены равного со всеми права голоса в управлении государством, то чрезвычайно высока вероятность того, что вашим интересам будет уделено меньше внимания, нежели интересам людей, обладающих правом голоса». ${ }^{17}$ Правильно, по поводу равенства избирательных прав граждан, высказался Перикл, в своей речи, посвященной памяти павших во время обороны Афин: «Наши рядовые граждане, хотя и заняты своими ремёслами и торговлей, способны здраво и мудро судить об общественных предметах». ${ }^{18}$ В связи с чем, каждый избиратель обладает голосом, имеющим равную, в том числе юридическую, силу по отношению к остальным голосам избирателей. Следовательно, гражданин обладая суверенной властью реализует свою власть путем подачи голоса, которое является ни чем иным, как властным решением, а значит, такое решение должно иметь письменную форму и обладать признаками преюдиции, как например, решение по делу об административном правонарушении. Здесь под преюдицией автором понимается юридическое предрешение наличия определенных фактов: подача голоса избирателем, соответствующее политическое решение (выбор) избирателя. Причем, письменная форма такого решения должна состоять из двух частей, каждое из которых имеет равную юридическую силу, одна часть представляется избирательной комиссии в виде бюллетеня, а другая часть, её можно назвать корешком бюллетеня, остается у избирателя и в случае необходимости может

${ }^{15}$ Нудненко Л.А. Теория демократии. М.: Юристъ, 2001. С. 63.

${ }^{16}$ Даль Р. О демократии / Пер с англ. А.С. Богдановского; под ред. О.А. Алякринского. М.: Аспект Пресс, 2000. С. 42.

${ }^{17}$ Даль Р. О демократии / Пер с англ. А.С. Богдановского; под ред. О.А. Алякринского. М.: Аспект Пресс, 2000. С. 76.

${ }^{18}$ Thucydides, Complete Writings: The Peloponnesian War. New York: Random Hause, 1951. P. 105. являться доказательством, того решения, которое было принято избирателем при голосовании.

Придание юридической силы такому документу создаст условия для возможности судебной защиты волеизъявления народа, в том числе признания недостоверными сведений внесенных избирательными комиссиями в избирательные документы. Ведь, по меньшей мере странно и неразумно, то обстоятельство, что избирательные комиссии являясь по своей сути только посредниками между народом и органами государственной власти обладают документами (например, протокол об итогах голосования, постановление о результатах выборов) имеющими юридическую силу, которые могут использовать в качестве доказательств в суде, а избиратель, частица народа, обладающий долей в суверенитете народа таких документов лишен и самостоятельно представить какие-либо избирательные документы в качестве доказательств в суде не может, их у него просто нет. Кроме того, сущность, например, протокола об итогах голосования, в том, что именно на основе этого не первичного, а вторичного документа, определяется волеизъявление народа и именно этот документ, в соответствии с законодательством, обладает юридической и доказательственной силой, а не какой-то другой. Хотя, по своей сути и правовой природе, бюллетень или его корешок, в которых, непосредственно зафиксировалось волеизъявление избирателя, являясь первичными избирательными документами, должны обладать большей юридической силой по сравнению с другими вторичными избирательными документами. Кроме того, если брать административные правоотношения, то в них даже решения единоличного должностного лица являются юридически значимыми решениями и находят выражения в письменной форме и могут выражаться в принудительном воздействии на многих лиц, тогда как в избирательных отношениях в которых презюмируется, что народ является источником власти, избиратель, являясь его частицей, лишен права при реализации своей суверенной воли при голосовании сохранять при себе письменный документ о фиксации своего волеизъявления, который касается только его самого и сохранял бы юридическую силу, хотя бы как решение административного органа в административном праве, а в случае необходимости мог быть представлен в суд в качестве доказательства.

В связи с чем, необходимым условием обеспечения конституционного принципа достоверности определения волеизъявления народа, является юридическая сила предоставленного гражданину письменного документа, в котором зафиксировано его волеизъявление 
с указанием на номер бюллетеня использованного им при голосовании.

Кроме того, необходимо установить погрешность в достоверности волеизъявления народа, чем оградить от возможностей необоснованного пересмотра избирательных документов о результатах непосредственного выражения власти народа, тогда когда они не влияют на результаты непосредственного выражения власти народа.

Представляется, что такая погрешность не может быть более или равна $1 \%$ от количества проголосовавших избирателей, чьи волеизъявления отражены в протоколе об итогах голосования участковой избирательной комиссии. В свою очередь, погрешность в 1\% и более является существенной в российских условиях, поскольку выборы в государственные законодательные органы власти проводятся, в том числе по пропорциональной системе и названная погрешность может влечь существенное изменение расклада политических сил в коллегиальном законодательном органе народного представительства.

Только в случае установления судом искажения волеизъявления избирателей в размере $1 \%$ и более от избирателей принявших участие в голосовании на избирательном участке, соответствующая избирательная комиссия или суд отменяет или признает недействительным протокол об итогах голосования на избирательном участке участковой избирательной комиссией.

Таким образом, условием обеспечения конституционного принципа достоверности волеизъявления народа, является отмена или признание недействительным протокола об итогах голосования на избирательном участке участковой избирательной комиссией, при искажении волеизъявления избирателей на $1 \%$ и более от избирателей принявших участие в голосовании на избирательном участке.

Приведенных условий обеспечивающих конституционный принцип достоверности волеизъявления народа недостаточно в случае отсутствия механизма наказания ответственных лиц за искажение волеизъявления народа. Раскрытие механизма ответственности за искажение волеизъявления народа остается за рамками настоящей статьи, и приводится в другой статье. ${ }^{19}$ Кроме того, те лица, которые оказывают содействия в достоверном определении волеизъявления народа, должны быть поощрены. Обоснование механизма поощрения за обеспечение достоверного волеизъявления

${ }^{19}$ Кравченко О.А. Ответственность за искажение волеизъявления народа // Адвокат. 2013. № 2. С. 55-61. народа остается за рамками настоящей статьи, и приводится в другой статье. ${ }^{20}$

Таким образом, установлены необходимые и достаточные условия для организации такой системы голосования, которая отвечала бы конституционному принципу достоверности определения результата волеизъявления народа с сохранением тайны голосования, к которым относятся следующие: 1) наличие механизма проверки избирателем учета своего волеизъявления (голоса); 2) наличие механизма защиты избирателем своего голоса в случае выявления несоответствий; 3) наличие механизма проверки избирателем достоверности определения результатов голосования; 4) наличие механизма защиты избирателем волеизъявления народа в случае выявления несоответствий; 5) наличие механизма проверки политической партией достоверности определения результатов голосования; 6) наличие механизма защиты политической партией волеизъявления народа в случае выявления несоответствий; 7) наличие механизма наказания ответственных лиц за выявленные и подтвержденные в судебном порядке факты искажения волеизъявления народа; 8) наличие механизма поощрения ответственных и заинтересованных лиц за выявленные и подтвержденные в судебном порядке факты искажения волеизъявления народа.

Содержащиеся в настоящей статье, выводы и предложения не рассматриваются как панацея, не являются исчерпывающими, а свидетельствуют о наличии большого числа нерешенных вопросов в исследуемой сфере, речь о которых пойдет в других статьях.

\section{Библиография:}

1. Алексеев С.С. Демократические реформы и конституция. М.: Издательский центр газеты «Позиция», 1992.

2. Баглай М.В., Габричидзе Б.Н. Конституционное право Российской Федерации. М.: 1996.

3. Даль Р. О демократии / Пер с англ. А.С. Богдановского; под ред. О.А. Алякринского. М.: Аспект Пресс, 2000.

4. Иванченко А.В. Избирательные комиссии в Российской Федерации: история, теория, практика. (Монографическое исследование). М.: Издательство «Весь Мир», 1996.

\footnotetext{
${ }^{20}$ Кравченко О.А. Поощрительные (позитивные) меры обеспечения достоверности волеизъявления народа // Право и государство: теория и практика. 2013. № 3 (99). С. 34-39.
} 
DOI: $10.7256 / 1811-9018.2013 .11 .10047$

При цитировании этой статьи сноска на dоі обязательна

\section{Право и политика 11 (166) • 2013}

5. Колюшин Е.И. Выборы и избирательное право в зеркале судебных решений: монография. 2-е издание переработанное и дополненное. М.: Норма: ИНФРА-М, 2012.

6. Кравченко О.А. Понятие и классификация искажений волеизъявления народа // Академический юридический журнал. 2013. № 3 (53).

7. Кравченко О.А Вопросы искажения волеизъявления народа при подведении итогов голосования // Актуальные проблемы российского права. 2013. № 9 (34).

8. Кравченко О.А. Демократия как достоверное волеизъявление народа // Вестник Пермского университета. Юридические науки. 2013. Выпуск 1(19).

9. Кравченко О.А. Суверенитет и воля народа (избирателей) // Вестник Тверского государственного университета. 2013. № 13. Серия «Право». Выпуск 34.

10. Кравченко О.А. Ответственность за искажение волеизъявления народа // Адвокат. 2013. № 2.

11. Кравченко О.А. Поощрительные (позитивные) меры обеспечения достоверности волеизъявления народа // Право и государство: теория и практика. 2013. № 3 (99).

12. Кравченко О.А. Вопросы процессуальных гарантий волеизъявления народа при формировании институтов народного представительства // Адвокатская практика. 2013. № 1.

13. Кравченко О.А. Процессуальные гарантии обеспечения достоверности волеизъявления народа: вопросы практики // Советник юриста. 2013. № 5.

14. Нудненко Л.А. Теория демократии. М.: Юристъ, 2001.

15. Thucydides, Complete Writings: The Peloponnesian War. New York: Random Hause, 1951.

\section{References (transliteration):}

1. Alekseev S.S. Demokraticheskie reformy i konstitutsiya. M.: Izdatel'skii tsentr gazety «Pozitsiya», 1992.

2. Baglai M.V., Gabrichidze B.N. Konstitutsionnoe pravo Rossiiskoi Federatsii. M.: 1996.

3. Dal' R. O demokratii / Per s angl. A.S. Bogdanovskogo; pod red. O.A. Alyakrinskogo. M.: Aspekt Press, 2000.

4. Ivanchenko A.V. Izbiratel'nye komissii v Rossii_skoi Federatsii: istoriya, teoriya, praktika. (Monograficheskoe issledovanie). M.: Izdatel'stvo «Ves' Mir», 1996.

5. Kolyushin E.I. Vybory i izbiratel'noe pravo v zerkale sudebnykh reshenii: monografiya. 2-e izdanie pererabotannoe i dopolnennoe. M.: Norma: INFRA-M, 2012.

6. Kravchenko O.A. Ponyatie i klassifikatsiya iskazhenii voleiz"yavleniya naroda // Akademicheskii yuridicheskii zhurnal. 2013. № 3 (53).

7. Kravchenko O.A Voprosy iskazheniya voleiz"yavleniya naroda pri podvedenii itogov golosovaniya // Aktual'nye problemy rossiiskogo prava. 2013. № 9 (34).

8. Kravchenko O.A. Demokratiya kak dostovernoe voleiz"yavlenie naroda // Vestnik Permskogo universiteta. Yuridicheskie nauki. 2013. Vypusk 1(19).

9. Kravchenko O.A. Suverenitet i volya naroda (izbiratelei) // Vestnik Tverskogo gosudarstvennogo universiteta. 2013. № 13. Seriya «Pravo». Vypusk 34.

10. Kravchenko O.A. Otvetstvennost' za iskazhenie voleiz”yavleniya naroda // Advokat. 2013. № 2.

11. Kravchenko O.A. Pooshchritel'nye (pozitivnye) mery obespecheniya dostovernosti voleiz"yavleniya naroda // Pravo i gosudarstvo: teoriya i praktika. 2013. № 3 (99).

12. Kravchenko O.A. Voprosy protsessual'nykh garantii voleiz"yavleniya naroda pri formirovanii institutov narodnogo predstavitel'stva // Advokatskaya praktika. 2013. № 1.

13. Kravchenko O.A. Protsessual'nye garantii obespecheniya dostovernosti voleiz"yavleniya naroda: voprosy praktiki // Sovetnik yurista. 2013. № 5.

14. Nudnenko L.A. Teoriya demokratii. M.: Yurist", 2001.

15. Thucydides, Complete Writings: The Peloponnesian War. New York: Random Hause, 1951. 